\title{
ULTRASTRUCTURAL CHANGES AND INTEGRITY OF GENOMIC DNA IN GERMINATED SEEDS OF Peltophorum dubium (Spreng.) TAUBERT SUBJECTED TO DRYING ${ }^{1}$
}

\author{
Cristiane Carvalho Guimarães ${ }^{2 *}$ Julio Maia Oliveira ${ }^{3}$, José Marcio Rocha Faria ${ }^{4}$ and Edvaldo Aparecido \\ Amaral da Silva ${ }^{5}$
}

\footnotetext{
${ }^{1}$ Received on 04.11.2014 accepted for publication on 18.08.2017.

${ }^{2}$ Universidade Federal de Lavras, Doutora em Engenharia Florestal, Lavras, Minas Gerais - Brasil. E-mail: <criscgbiologia@hotmail.com>. ${ }^{3}$ Universidade de Wageningen, Departamento de Fisiologia de Plantas, Wageningen - Holanda. E-mail: <juliomaia2@hotmail.com>. ${ }^{4}$ Universidade Federal de Lavras, Departamento de Ciências Florestais, Lavras Minas Gerais - Brasil. E-mail: <jmfaria@dcf.ufla.br>. ${ }^{5}$ Universidade Estadual Paulista, Departamento de Produção Vegetal, Botucatu, São Paulo - Brasil. E-mail:<amaraldasilva@fca.unesp.br>. *Corresponding author.
}

\begin{abstract}
The aim of this study was to evaluate DNA integrity and to identify ultrastructural changes in the primary root of Peltophorum dubium seeds subjected to drying, since these changes may reflect the germination capacity. Seeds were germinated and were dehydrated when reached $1 \mathrm{~mm}$ in length of the primary root, until reaching different moisture contents, being then rehydrated and evaluated in relation to survival. After this procedure, different points of interest (control, 20\% and 10\% moisture content) were selected to evaluate DNA and cell ultrastructure integrity in order to detect possible cellular changes in primary roots after dehydration. When dried down to $32 \%$ moisture, there was no influence on the growth resumption of the germinated seeds, but when they were dehydrated to $20 \%$ moisture, the survival was reduced to $67 \%$, reaching nullity in the survival with drying to $8 \%$ moisture. By the evaluation of ultrastructural changes in root cells, it was observed that drying to approximately $20 \%$ moisture content marked the onset of damages by desiccation, both physiologically and ultrastructurally. Drying to levels close to $10 \%$ moisture content was not only responsible for total disorganization and rupture of membranes, but also promoted intracellular collapse. Loss of genomic DNA integrity was observed during drying.
\end{abstract}

Keywords: Desiccation tolerance; Cellular alterations; DNA damage.

\section{MUDANÇAS ULTRA-ESTRUTURAIS E INTEGRIDADE DO DNA GENÔMICO EM SEMENTES GERMinAdAS DE PELTOPHORUM DUBIUM SUBMETIDAS $\dot{A}$ SECAGEM.}

\begin{abstract}
RESUMO-Objetivou-se com esse trabalho avaliar a integridade do DNA e identificar mudanças ultra-estruturais em raiz primária de sementes de Peltophorum dubium submetidas a secagem. Para tanto, sementes foram posta a germinar e ao atingirem $1 \mathrm{~mm}$ de comprimento da raiz primária, foram desidratadas, até atingirem diferentes graus de umidade, sendo em seguida reidratadas e avaliadas quanto à sobrevivência. Após esse procedimento foram selecionados diferentes pontos de interesse (controle, 20\% e 10\% de umidade) para avaliação da integridade do DNA e da ultraestrutura celular no intuito de detectar possíveis mudanças celulares nas raizes primárias após desidratação. Quando secas até 32\% de umidade não houve influência na retomada do crescimento das sementes germinadas, mas ao serem desidratadas a $20 \%$ de umidade, a sobrevivência foi reduzida a $67 \%$ e a secagem a 8\% de umidade concorreu para nulidade na sobrevivência. Pela avaliação de mudanças ultraestruturais em células da raiz observou-se que secagem a aproximadamente $20 \%$ de umidade marcou o início dos danos por dessecação, tanto fisiológica quanto ultraestruturalmente. Secagem a níveis próximos a 10\% de umidade concorreu não somente para total desconfiguração e ruptura das membranas como também promoveu colapso intracelular. Foi observada perda da integridade do DNA genômico no decorrer da secagem.
\end{abstract}

Palavras-Chave: Tolerância à dessecação, alterações celulares, danos ao DNA 


\section{INTRODUCTION}

The phenomenon of desiccation tolerance in any system can be assessed by the extent of cell survival during dehydration and subsequent rehydration. According to Berjak et al. (1984), it is likely that a genetic mechanism will act to control the dehydration process during maturation of orthodox seeds, which appear to have their origins in drought-prone areas that are not always favorable to germination. However, in recalcitrant seeds that tend to originate from humid places and therefore suitable for the germination process continuously, this genetic mechanism may not be present, and even if it is, it is not functional. Among the several known protection mechanisms, it has been reported that desiccation tolerance depends on the ability to repair genomic DNA damage and maintain the integrity of the seeds' anatomical structures during drying (Osborne and Boubriak, 1997; Moore et al., 2009).

It is known that DNA is subject to damage by drying and that cells have strategies to respond to these lesions. The maintenance of the genetic information contained in DNA is essential for the cell survival and it is proposed that the desiccation tolerance in seeds depends on the capacity to repair damages to the genomic DNA when the embryo is dehydrated and later rehydrated. Tolerance can be achieved through mechanisms that incorporate one of the two alternatives, i.e. cell protection or recovery (Oliver, 1996; Osborne et al., 2002).

It was also reported that anatomical changes could occur in plants under water deficit, aiming at protection and adaptation of the species to this stress. These morphological and anatomical variations have been extensively studied in vegetative tissues, but still little known in seeds. Basic information concerning physiological aspects related to such variations, especially under water stress conditions, may be very useful in understanding the different drying responses showed by recalcitrant and orthodox seeds since membranes of the cellular organelles, the cytoskeleton, among others, are essential for the perfect cell functioning, and damages to these structures can lead to the rapid viability loss (Berjak and Pammenter, 2000).

Thus, the aim of this study was to evaluate DNA integrity and to identify ultrastructural changes in the primary root of Peltophorum dubium (Spreng.) Taubert seeds, Leguminosae family, subjected to drying. The species under study produces orthodox seeds and therefore can be used as a tool for the study of desiccation sensitivity when germinated.

\section{MATERIALAND METHODS}

The fruits were manually harvested from trees growing in the Federal University of Lavras (UFLA), MG, Brazil. Following, they were broken down and sieves were used to separate part of the impurities. The removal of the remaining impurities present in the sample was performed with South Dakota and General Type blowers.

The pre-germinative treatment used to break physical dormancy was performed by immersing the seeds in hot water $\left(96^{\circ} \mathrm{C}\right)$ and, for greater efficiency in the tegument softening process, they were kept immersed in water for $24 \mathrm{~h}$ at room temperature (Oliveira et al., 2003). After this procedure, they were set to germinate on paper (Perez et al., 1999), moistened with distilled water until saturation (Brasil, 1992), in plastic trays and conditioned in germinators (Marconi type MA 400) at $25^{\circ} \mathrm{C}$, with photoperiod of $12 \mathrm{~h}$.

To assess loss of desiccation tolerance after germination, the germinated seeds with primary root of $1 \mathrm{~mm}$ length were sampled for this test, in four replications of 20 seeds for each of the following treatments: drying at 59\%, 50\%, 38\%, 32\%, 20\%, and $8 \%$ moisture. To achieve these moisture contents, the dehydration was done in gerbox plastic boxes with seeds on a screen and a layer of silica gel in the bottom at $20^{\circ} \mathrm{C}$ in the dark. During dehydration, successive weighings were performed until the found weight coincided with the target weight, corresponding to the target moisture content through the expression proposed by Cromarty et al. (1985).

After dehydration, the seeds were pre-moistened in humid air $(100 \% \mathrm{RH})$ for $24 \mathrm{~h}$ at $25^{\circ} \mathrm{C}$ in order to prevent possible damages caused by rapid soaking (Crowe et al., 1989) and subsequently placed in the same conditions used for germination. The germinated seeds that kept up their development and formed normal seedlings were considered as desiccation tolerant.

Based on survival data obtained after the evaluation of the loss of desiccation tolerance, different points of interest were selected to evaluate DNA integrity and cellular morphology, being: $68 \%$ (control), $20 \%$ and $8 \%$ moisture content.

DNA extraction was performed on $1 \mathrm{~mm}$ long primary roots after drying using approximately 150 roots divided into three replicates per treatment, based on the CTAB protocol of genomic DNA microextraction (Ferreira and

Revista Árvore. 2017;41(4):e410411

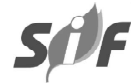


Grattapaglia, 1995). The integrity of the same was analyzed in $1 \%$ agarose gel and later were applied in the gel and subjected to electrophoresis for $40 \mathrm{~min}$ at $100 \mathrm{~W}$, recording the images.

In order to investigate possible ultrastructural changes, five primary roots were observed per treatment and the cuts were performed with the Reichert-Jung ultramicrotome, whose diamond blade allowed sectioning tissues with a thickness of less than $100 \mathrm{~nm}$, which were colored with uranyl acetate followed by lead citrate ( $3 \mathrm{~min}$ each). The images of cells from the root meristem were captured with transmission electron microscope (Zeiss EM 109, Carl Zeiss, Jena, Germany) at $80 \mathrm{kV}$.

\section{RESULTS}

Peltophorum dubium seeds germinate easily, showing about $90 \%$ of normal seedlings when subjected to adequate pre-germinative treatment. When release of physical dormancy was performed, the root protrusion was observed in most of seeds in $72 \mathrm{~h}$.

To evaluate the gradual loss of desiccation tolerance (DT) in germinated seeds of Peltophorum dubium in order to use them as a model for studies concerning the molecular aspects involved in this process, these were analyzed regarding survival after the gradual removal of water. The results are shown in Figure 1.

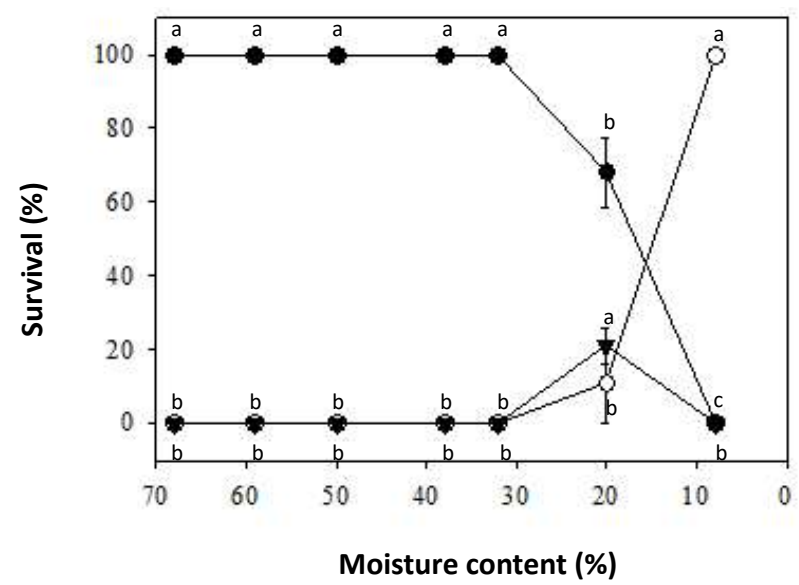

Figure 1 - Behavior of germinated seeds of Peltophorum dubium when subjected to different levels of drying and subsequent rehydration. Normal seedlings (Ï\%), Dead seeds (Ë\%) and Abnormal seedlings (2\%).

Figura 1 - Comportamento de sementes germinadas de Peltophorum dubium quando submetidas a diferentes niveis de secagem e posterior reidratação. Plântulas normais (Ï\%), Sementes mortas (Ë\%) e Plântulas anormais (2\%).
Based on the presented results, different and representative DT levels were selected for later observation of possible ultra-structural damages and integrity of the genomic DNA after drying. The referred DT stages were sampled considering the contrasting points in relation to survival percentage of seeds, being: germinated seeds (moisture content corresponding to $68 \%$ and survival of $100 \%$ ), dry seeds at $20 \%$ moisture content ( $67 \%$ of survival) and dry seeds at initial moisture levels ( $8 \%$ moisture and null survival).

Regarding the microscopy analyses, it can be stated that the non-dehydrated primary roots of Peltophorum dubium showed differentiated mitochondria, as evidenced by the presence of small cristae (Figure 2B and 2C). Prominent nuclei (Figure 2A), endoplasmic reticulum (Figure 2D), cell wall integrity (Figure 2A, $2 \mathrm{~B}$ and $2 \mathrm{C}$ ) and small vacuolization degree (Figure 2B) were observed in the root meristem. Close to the plasmalemma (Figure 2C), equally intact and attached to the cell wall, the presence of aligned lipid grains was detected (Figure 2C).

When they were dried to $20 \%$ moisture content, some ultrastructural abnormalities were detected, such as dilatation and confluence of vacuoles (Figure 3C), regression of mitochondrial cristae (Figure 3B), principle of cell wall plasmalemma separation (Figure 3B) and amorphous nuclei emergence.

However, drying to levels close to $10 \%$ moisture content was not only responsible for total disorganization and rupture of membranes, but also promoted intracellular collapse.

The electrophoretic profile of DNA extracted from $1 \mathrm{~mm}$ long primary roots is shown in Figure 5. DNA integrity is evident in primary roots of germinated seeds (68\% moisture content) not subjected to drying (Figure $5-1)$. For seeds dried to $20 \%$ moisture content, the degradation of the genetic material was observed, as evidenced by the smearing on gel when compared to the control (Figure $5-2 \mathrm{a}, 2 \mathrm{~b}$ and $2 \mathrm{c}$ ) and drying at hydration levels close to $10 \%$ caused complete degradation of the genomic DNA (Figure 5-3a, b and c), coinciding with the nullity of their survival.

\section{DISCUSSION}

According to the results regarding the gradual process of DT loss in the studied species, a decrease in survival was observed as the moisture content of

Revista Árvore. 2017;41(4):e410411 

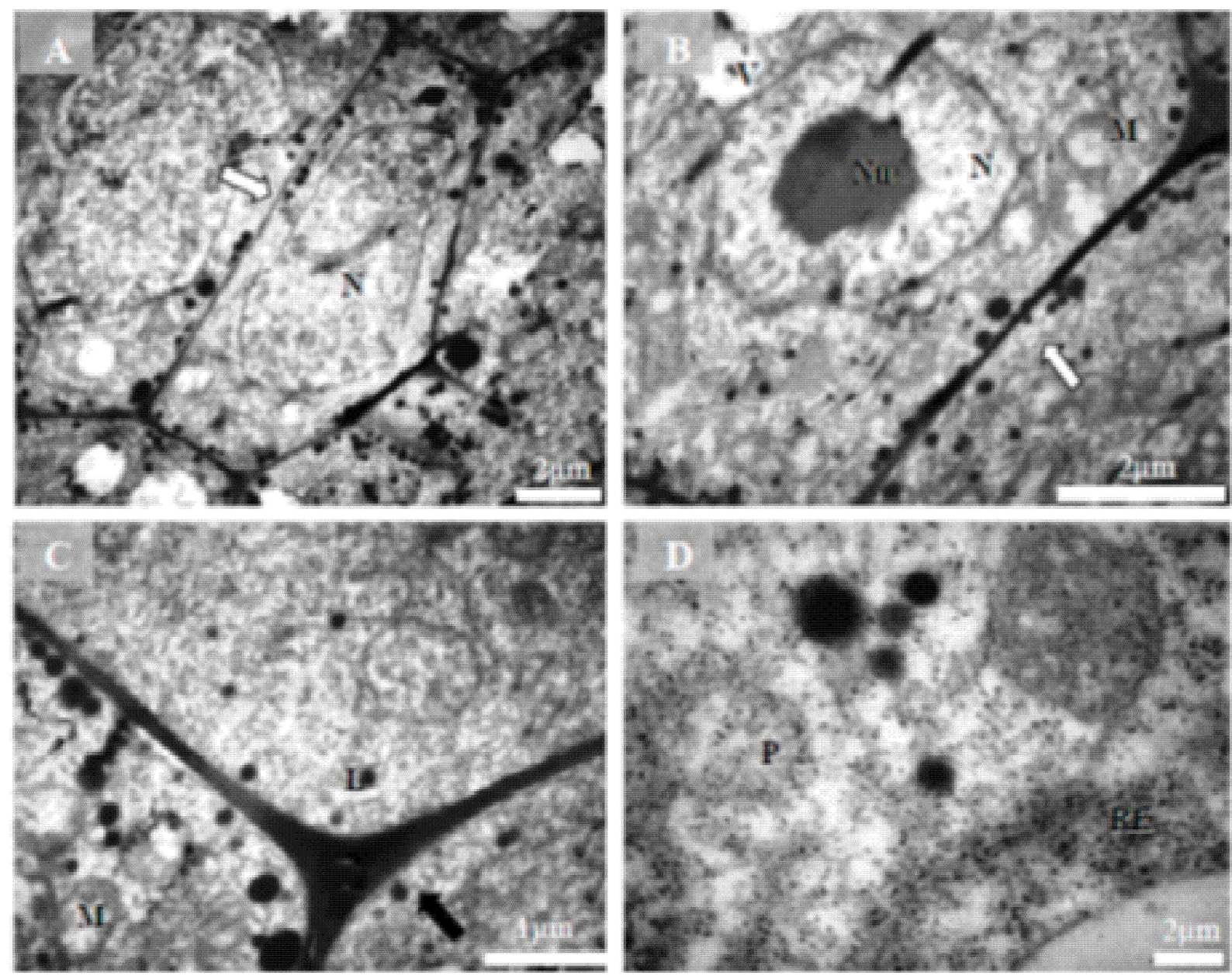

Figure 2 - Cellular aspect of the root meristem of Peltophorum dubium intact seeds evaluated by transmission electron microscopy. A. Intact cell, perfectly delimited by cell wall (arrow) and prominent nucleus (N); B. Small vacuoles $(\mathrm{V})$, nucleolus $(\mathrm{Nu})$, nucleus $(\mathrm{N})$, mitochondria (M), cell wall (arrow); C. Mitochondria (M), lipid bodies (L), plasma membrane (arrow) and absence of intracellular space; D. Endoplasmic reticulum (ER) and polysomes (P).

Figure 2 - Aspecto celular do meristema radicular de sementes de Peltophorum dubium integras avaliadas através de microscopia eletrônica de transmissão. A. Célula intacta, perfeitamente delimitada por parede celular (seta clara) e núcleo proeminente $(N)$; B. Pequenos vacúolos $(V)$, nucléolo $(N u)$, núcleo $(N)$, mitocôndrias $(M)$, parede celular (seta); C. Mitocôndrias (M), corpos lipídicos (L), membrana plasmática (seta escura) e ausência de espaço intracelular; D. Retículo endoplasmático (RE) e polissomos $(P)$.

seeds was reduced (Figure 1). It is possible to observe that the survival percentage was not affected when they were desiccated to approximately $30 \%$ moisture content. However, drying to moisture levels below this value $(20 \%)$ caused reduction in survival and these values were null when dehydrated to the initial moisture content levels $(8 \%)$.

Walters (2000) considered that the seed needs different protection systems at each level of water removal to tolerate dehydration and therefore would have its tolerance degree conditioned to the type of water removed at each stage and the presence of these systems. According to Vertucci and Farrant (1995), the moisture contents between $10 \%$ and $20 \%$, which represent lethal contents of water for most species with recalcitrant seeds, characterize water bound to hydrophilic sites, and there is no more synthesis of proteins and nucleic acids. This statement corroborates data obtained in this study, where drying of germinated seeds of

Revista Árvore. 2017;41(4):e410411 

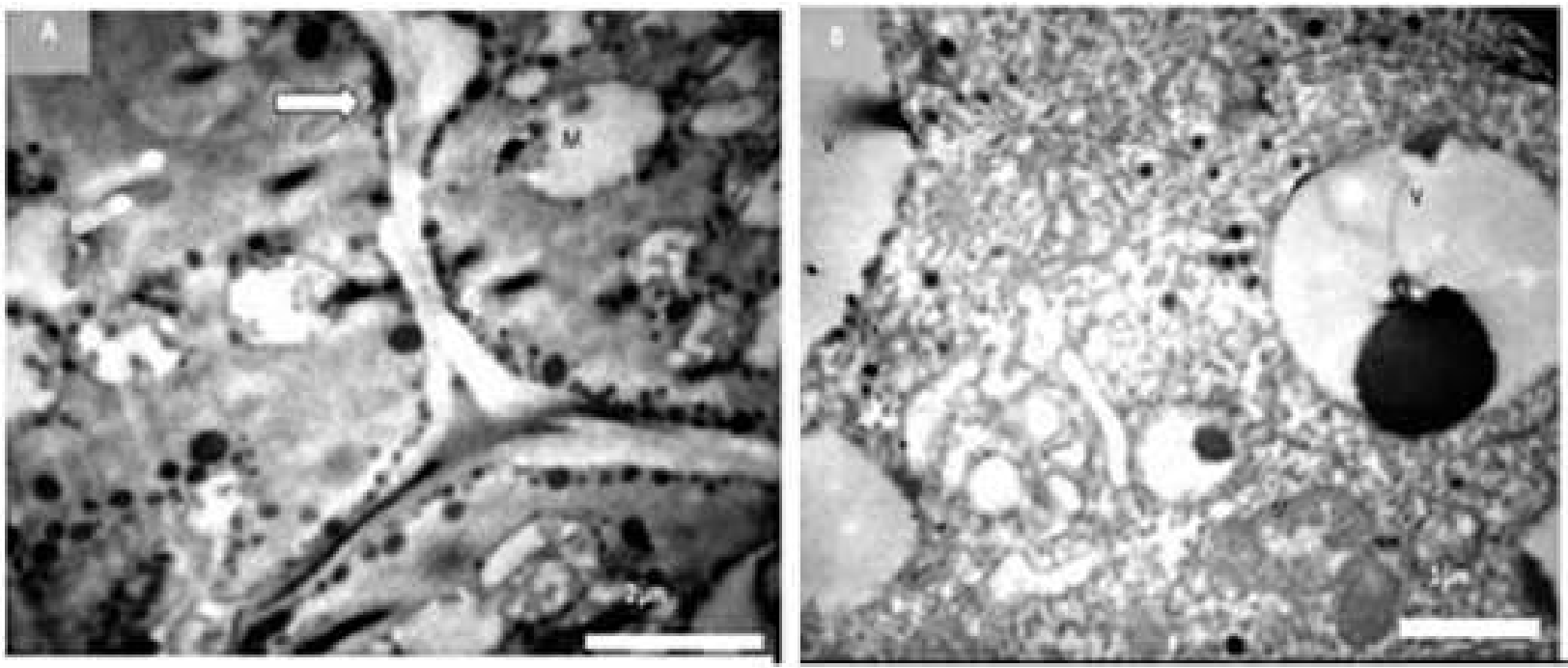

Figure 3 - Ultrastructure of embryonic cells of Peltophorum dubium seeds subjected to dehydration to $20 \%$ moisture. A. Cell wall with atypical undulating appearance and change in plasma membrane integrity showed by the onset of cell wall separation (arrow), evidence of mitochondrial cristae reduction (M) and irregular folds in the cell wall; B. Increment to the size of vacuoles (V) possibly due to autophagy.

Figura 3 - Ultraestrutura de células embrionárias de sementes de Peltophorum dubium submetidas à desidratação a $20 \%$ de umidade. A. Parede celular com atípica aparência ondulada e alteração na integridade da membrana plasmática demonstrado pelo início da separação desta da parede celular (seta clara), evidências de redução das cristas mitocondriais (M) e dobras irregulares na parede celular (seta clara); B. Incremento ao tamanho dos vacúolos (V), possivelmente devido à autofagia.
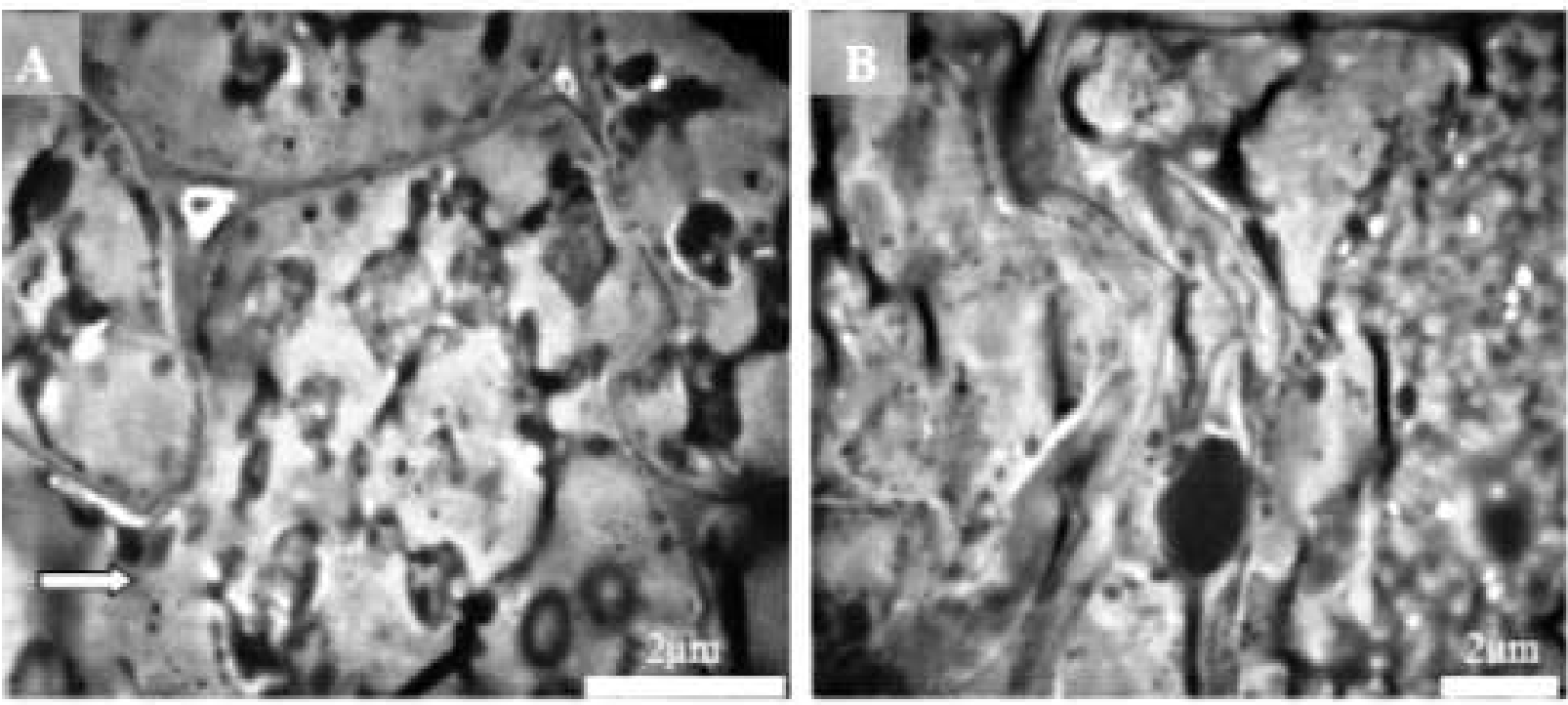

Figure 4 - Subcellular aspect of the root meristem of Peltophorum dubium seeds subjected to dehydration to $8 \%$ moisture. A. Disruption of cell wall (arrow); B. Intracellular collapse.

Figura 4 - Aspecto subcelular do meristema radicular de sementes de Peltophorum dubium submetidas à desidratação a $8 \%$ de umidade. 


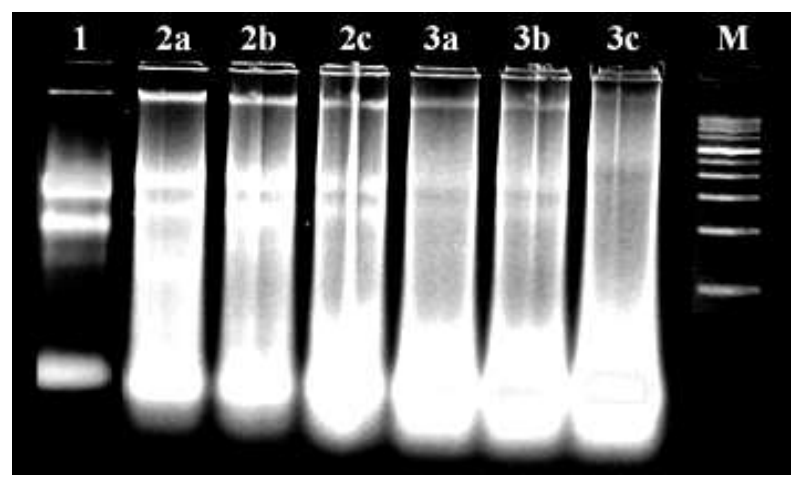

Figure 5 - Electrophoretic profile of DNA extracted from $1 \mathrm{~mm}$ long primary roots to assess the integrity of genomic DNA in germinated seeds of Peltophorum dubium subjected to silica gel drying. 1. Seeds not subjected to drying; 2a, 2b and 2c. Seeds dried to $20 \%$ moisture content; $\mathbf{3 a}, \mathbf{3 b}$ and $\mathbf{3 c}$. Seeds dried to $8 \%$ moisture content. M. Molecular weight marker $1 \mathrm{~Kb}$

Figura 5 - Perfil eletroforético de DNA extraído de raizes primárias com $1 \mathrm{~mm}$ de comprimento, para avaliação da integridade do DNA genômico em sementes germinadas de Peltophorum dubium submetidas à secagem em sílica gel. 1. Sementes não submetidas à secagem; 2 a, 2 b e 2 c. Sementes secas a $20 \%$ de umidade; 3 a, 3 b e 3 c. Sementes secas a $8 \%$ de umidade. M. Marcador de peso molecular $1 \mathrm{~Kb}$.

Peltophorum dubium to $20 \%$ moisture content and subsequent rehydration caused a significant drop in the survival percentage $(68 \%)$, increase in the number of abnormal seedlings (21\%) and in the mortality (11\%).A

Microscopic analyses performed on primary roots of Peltophorum dubium with $1 \mathrm{~mm}$ length and moisture contents of 68,20 , and $8 \%$ elucidate that the transition from the tolerance stage to the desiccation sensitivity was accompanied by physical and structural changes in the cells. Evidenced in Figure 2A, the structures shown on seeds not subjected to drying indicate active metabolism. The integrity of these structures is extremely important for cell functioning and naturally essential for seedling survival and growth. Ultrastructural damage may contribute to reduced germination capacity and consequent partial or total increase in seed mortality.

Primary roots of Peltophorum dubium not dehydrated appeared to have differentiated mitochondria, as evidenced by the presence of small cristae (Figure 2B and 2C) and it is known that the number and degree of development of these structures are correlated with high metabolic rate (Berjak and Pammenter, 2000). Prominent nuclei (Figure 2A), endoplasmic reticulum (Figure 2D), cell wall integrity (Figure 2A, 2B and 2C) and small vacuolization degree (Figure 2B) were observed in the root meristem. Close to the plasmalemma (Figure 2C), equally intact and attached to the cell wall, the presence of aligned lipid grains was detected (Figure 2C). A similar pattern was described by Cordova-Tellez and; Burris (2002), in studies with Zea mays seeds. These authors reported that the alignment of lipid bodies along the plasma membrane can reduce the cell surface exposed to water loss, resulting in changes in the water relations among cells and hence in more organized dehydration during the drying process of seeds.

The integrity of the plasma membrane is considered essential for the maintenance of seed viability, since it keeps cell integrity and delimits the boundary between the intracellular and extracellular media, constituting a selective barrier, through which substances and energy exchanges are processed between the cell and the external environment, also functioning as a sensor, allowing the cell to modify in response to several environmental stimuli. However, with drying, they undergo a process of structural disorganization, being as more disorganized as the lower the moisture content of seeds and thus verifying a higher leaching degree of electrolytes from the interior of cells to the external environment, lack of control of hybrid exchanges and full cell decompartmentalization (Bewley and Black, 1985; Corrêa and Afonso Júnior, 1999; Santos et al., 2004).

The data suggest that drying to approximately $20 \%$ water content marked the onset of damage by desiccation both physiologically and ultrastructurally. This was evident in some structures, particularly the cell walls that showed atypical undulating appearance, considered as indicative of prolonged water stress of seeds (Figure 3A; 3B). However, a small change in membrane permeability does not necessarily result in viability loss. Tissue death results when a critical portion of cells loses membrane integrity (Leprince et al., 1999). This statement confirms the $67 \%$ survival of Peltophorum dubium seeds when dried to $20 \%$ moisture, even when certain ultrastructural abnormalities are observed.

There were dilation and confluence of vacuoles (Figure 3C), probably due to autophagy, where severely damaged cytoplasmic components are removed and broken within them (Berjak and Pammenter, 2000;

Revista Árvore. 2017;41(4):e410411 
Corbineau et al., 2004), however, they remain intact without extravasation of the internal content. Other stress indications were the regression of mitochondrial cristae (Figure 3B), beginning of plasmalemma separation from the cell wall (Figure 3B) and appearance of amorphous nuclei.

However, drying to levels close to $10 \%$ moisture content was responsible for total disorganization, rupture of membranes and also promoted intracellular collapse (Figure 4). The plasmalemma was completely detached from the cell wall and every cell showed disorganization to a level that it became virtually impossible to discern individual organelles. Vacuoles, previously observed and perfectly delimited by membrane, disappeared. It is worth mentioning that this is an important factor that contributes to the loss of seed viability due to cellular damage promoted by the vacuolar content released after the rupture. These structures are involved in the maintenance of the osmotic potential of cell plant and the isolation of toxic enzymes and metabolites, which underscores the importance of their integrity. Rosseto (1997), in studies with Xerophyta plicata and Nanuza plicata, observed that vacuoles are fragmented into smaller vacuoles, but without membrane rupture in these two species tolerant to desiccation. This mechanism prevents the overflow of enzymes and incompatible substances that exist in these compartments.

Besides stress responses, due to rapid water removal, lipids disappeared in response to excessive energy consumption or due to oxidation processes, according to Elias et al. (2009), which mentioned this possible consequence. According to these authors, the reduction in lipid content is related directly to the speed and intensity of the deterioration process, since they are considered the constituents most susceptible to chemical degradation and deterioration process. The reduction of lipid content and the increase in the free fatty acids content resulting from the hydrolysis of these reserve substances constitute an efficient parameter for the control of seed viability (Rupollo et al., 2004; Marini et al., 2005). High drying rates of the embryo may also contribute to prevent or disorganize the alignment of lipid bodies along the plasma membrane that, as previously described, corroborate with a more organized dehydration (Cordova-Tellez and Burris, 2002).

Faria et al. (2005), in ultrastructural analysis performed on embryonic axes of Inga vera, a species whose seeds are considered as highly recalcitrant, observed similar abnormalities when they were stored, such as folds in the cell wall, cytoplasm degradation and amorphous nuclei. These results confirm the assertion that considerable damages occur because of dehydration and validate the results related to the seed survival from the species under study, which showed $100 \%$ mortality when dried to $8 \%$ moisture content. Similar ultrastructural changes have been described in several studies on damage by drying (Deltour and Barsy, 1985; Corbineau et al., 2004; Kioko et al., 2006; Silva et al., 2007).

It is known that DNA is subject to damage by drying and that cells have strategies to respond to these lesions. The maintenance of the genetic information contained in DNA is essential for the cell survival and it is proposed that the desiccation tolerance in seeds depends on the capacity to repair damages to the genomic DNA when the embryo is dehydrated and later rehydrated. Tolerance can be achieved through mechanisms that incorporate one of the two alternatives, i.e. cell protection or recovery (Oliver, 1996; Osborne et al., 2002).

As previously described, in order to correlate severe drying with damage to genomic DNA, the seed integrity was evaluated when germinated seeds of Peltophorum dubium were subjected to drying at 20 and $8 \%$ moisture; where the onset of physiological damage was observed by drying with reduction in percentage of survival and increase in the percentage of abnormal seedlings. The electrophoretic profile of DNA extracted from 1 $\mathrm{mm}$ long primary roots is shown in Figure 5.

DNA integrity is evident in primary roots of germinated seeds ( $68 \%$ moisture content) not subjected to drying (Figure 5-1). The importance of DNA repair in determining the plant genome should be highlighted, emphasizing that the ability to resume the synthesis of proteins, lipids and RNA is only performed if the integrity of genetic information was also conserved (Osborne and Boubriak, 1997).

For seeds dried to $20 \%$ moisture content, the degradation of the genetic material was detected, as evidenced by the smearing on the gel when compared to the control (Figure 5). The literature describes two processes of cell death and these can be detected by observing the DNA degradation pattern on gel. Apoptosis describes an active process of cell collapse that morphologically differs from death by necrosis. It is a type of programmed cell death that occurs during several 
physiological and pathological situations, constituting a removal mechanism for damaged cells and a cellular and tissue renewal, without disintegration of organelles. Due to the activation of endonucleases responsible for the cleavage of DNA into fragments, the pattern observed on the gel in these cases is similar to a ladder (Stein and Hansen, 1999; Anazetti and Melo, 2007). On the other hand, necrosis generally occurs in response to severe cell injury and is characterized by loss of plasma membrane integrity, chromatin flocculation, swelling followed by cell lysis with intracellular content overflow and organelle disintegration (Curtin et al., 2002). The smearing on the gel in the present study (Figure 5) characterizes this process.

According to Marcos Filho (2005), the reduction of the integrity of the genetic material of seeds shows that DNA and proteins involved in its metabolism are prone to deterioration and the lesions provoked can be translated into germination disturbances. This assertion validates the results obtained in this study, since the decline in the percentage of seed survival from this species $(67 \%)$ coincides with the observation for degradation of genomic DNA. The degradation observed in the gel, essentially in the repetitions $2 \mathrm{~b}$ and $2 \mathrm{c}$ of Figure 5 , comes from $11 \%$ of primary roots that did not survive to drying and probably also from the seeds that, damaged by drying, resulted in abnormal seedlings $(21 \%)$.

According to a study performed by Boubriak et al. (1997), one of the initial events during soaking is the action of repair mechanisms of probable damage to the DNA. Blockages to the performance of these mechanisms contribute to the degradation increase of the genomic DNA and compromise the seed performance. The inefficiency of these mechanisms possibly contributed to the mortality increase (11\%) and to the formation of abnormal seedlings (21\%) when the seeds were dehydrated to $20 \%$ water content. Studies related to the deterioration have been directing more attention to the repair processes during germination, mainly DNA recovery. The presence of damaged DNA in non-germinated seeds has been verified; however, there are doubts if these injuries are the cause or consequence of deterioration (Marcos Filho, 2005).

In germinated seeds of Peltophorum dubium, drying at hydration levels close to $10 \%$ caused complete degradation of genomic DNA (Figure $5-3 a, b$ and c), coinciding with nullity in their survival. The observed degradation pattern corresponds to death from necrosis, usually reported when the stress degree is above a particular level. Masetto et

Revista Árvore. 2017;41(4):e410411 al. (2008) observed a similar degradation pattern and loss of genomic DNA integrity in studies with Eugenia pleurantha seeds and germinated seeds of Sesbania virgata and Cedrela fissilis subjected to drying. Differing only as regards the degradation pattern, in germinated seeds of Medicago truncatula (Faria et al., 2005), DNA degradation was also observed when they were dehydrated, ratifying the losses promoted by drying.

During deterioration, the nuclear DNA is progressively fragmented and proteins are denatured simultaneously, where DNA repair enzymes lose their function. During soaking, the recovery of genome integrity and the resumption ofDNA synthesis are delayed and can be completely inhibited. Thus, embryo cells lose their survival potential (Marcos Filho, 2005), sanctioning, as previously mentioned, nullity in the survival of dried Peltophorum dubium seeds at the initial levels of hydration and complete degradation of the genomic DNA evidenced through the electrophoretic profile. It is known that several strategies to tolerate or repair damage to the cell genetic material have been selected, however, severe stresses contribute to their stability, and the inability to repair damage to the DNA of cells was possibly crucial for survival of the germinated seeds of Peltophorum dubium.

Although there is considerable progress in understanding molecular responses to cell stresses, much still needs to be studied for a better understanding of the relationship between cell stress, cell cycle transition control, DNA repair, and decision between survival or death (Berra and Menck, 2006).

\section{CONCLUSIONS}

There was a correlation between reduction of water content and decrease of the survival capacity in germinated seeds of Peltophorum dubium. It was observed that hydration levels below $10 \%$ moisture content were lethal to the germinated seeds, and microscopic evaluations were efficient in evidencing ultrastructural damages in cells subjected to drying. There was a direct relationship between DNA degradation after drying of germinated seeds and loss of desiccation tolerance.

\section{REFERENCES}

Anazetti MC, Melo PS. Morte celular por apoptose: uma visão bioquímica e molecular. Metrocamp Pesquisa. 2007;1(1):37-58.

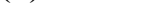


Berjak P, Dini M, Pammenter NW. Possible mechanisms underlying the differing dehydration responses in recalcitrant and orthodox seeds: desiccation-associated subcellular changes in propagules of Avicennia marina. Seed Science and Technology. 1984;12(3):365-84.

Berjak P, Pammenter N. What ultrastructure has told us about recalcitrant seeds. Revista Brasileira de Fisiologia Vegetal. 2000;12:22-55.

Berra CM, Menck CFM. Estresse oxidativo, lesões no genoma e processos de sinalização no controle do ciclo celular. Química Nova. 2006;29(6):1340-44.

Bewley JD, Black M. Seeds: physiology of development and germination. New York: Plenum; 1985.367p.

Brasil. Ministério da Agricultura e Reforma Agrária. Regras para análise de sementes. Brasília, DF: SNAD/DNDV/CLAV; 1992.365p.

Boubriak I, Kargiolaki H, Lyne L, Osborne DJ. The requirement for DNA repair in desiccation tolerance of germinating embryos. Seed Science Research. 1997;7(1):97-105.

Corbineau F, Berjak P, Pammenter N, Vinel D, Picard MA, Come D. Reversible cellular and metabolic changes induced by dehydration in desiccation-tolerant wheat seedling shoots. Physiologia Plantarum. 2004;122(1):28-38.

Cordova-Tellez, L, Burris JS. Alignment of lipid bodies along the plasma membrane during the acquisition of desiccation tolerance in maize seed. Crop Science. 2002;42(6):1982-8.

Corrêa PC, Afonso Júnior PC. Uso do teste de condutividade elétrica na avaliação dos danos provocados por diferentes taxas de secagem em sementes de feijão. Revista Brasileira de Produtos Agroindustriais. 1999;1(1):21-6.

Cromarty AS, Ellis RH, Roberts EH. Design of seed storage facilities for genetic conservation. Rome: IPGRI; 1985. 100p.

Crowe JH, Crowe LM, Hoekstra FA. Phase transitions and permeability changes in dry membranes during rehydration. Journal of Bioenergetics and Biomembranes. 1989;21(1):77-91.
Curtin JF, Donovan M, Cotter TG. Regulation and measurement of oxidative stress in apoptosis. Journal of Immunological Methods. 2002;265(1):49-72.

Deltour R, Barsy T. Nuclear activiation during early germination of the higher plant embryo. Journal of Cell Science. 1985;75(1):43-83.

Elias, MC, Lopes, V. Gutkoski, LC. Oliveira, M. Mazzuuti, S. Dias, ARG. Umidade de colheita, métodos de secagem e tempo de armazenamento na qualidade tecnológica de grãos de trigo. Ciência Rural, Santa Maria, 2009;39(1): 25-30.

Faria JMR, Buitink J, van Lammeren AAM, Hilhorst HWM. Changes in DNA and microtubules during loss and re-establishment of desiccation-tolerance in germinating Medicago truncatula seeds. Journal of Experimental Botany. 2005;56(418):2119-30.

Ferreira ME, Grattapaglia D. Introdução ao uso de marcadores moleculares em análise genética. $2^{\mathrm{a}}$ ed. Brasília, DF: Embrapa/CENARGEN; 1995. 220p.

Kioko JI, Berjak P, Pammenter NW. Viability and ultrastructural responses of seeds and embryonic axes of Trichilia emetica to different dehydration and storage conditions. South African Journal of Botany. 2006;71(2):167-76.

Leprince O, Buitink J, Hoekstra FA. Axes and cotyledons of recalcitrant seeds of Castanea sativa Mill. exhibit contrasting responses of respiration to drying in relation to desiccation sensitivity. Journal of Experimental Botany.1999;50(338):1515-24.

Marcos Filho J. Fisiologia de sementes de plantas cultivadas. Piracicaba: Fealq; 2005. 495p.

Marini LJ, Gutkoski C, Elias MC, Mezzomo N. Efeito da secagem intermitente na estabilidade de grãos de aveia. Brazilian Journal of Food Technology. 2005;8(3):260-7.

Masetto TE, Faria JMR, Davide A, Silva EAA. Desiccation tolerance and dna integrity in Eugenia pleurantha o. berg. (myrtaceae) seeds. Revista Brasileira de Sementes. 2008;30(1):175-80. 
Moore JP, Le NT, Brandt WF, Driouich A, Farrant JM. Towards a systems-based understanding of plant desiccation tolerance. Trends in Plant Science 2009; 14: 110-7.

Oliveira LM, Davide AC, Carvalho MLM. Avaliação de métodos para quebra de dormência e para desinfecção de sementes de canafistula (Peltophorum dubium (Sprengel) Taubert. Revista Árvore. 2003;27(5):1-8.

Oliver MJ. Desiccation tolerance in vegetative plant cells. Physiologia Plantarum. 1996;97(4):779-87.

Osborne DJ, Boubriak II. DNA status, replication and repair in desiccation tolerance and germination: basic and apllied aspects of seed biology. In: Ellis RH, Black M, Murdoch AJ, Hong TD, editor. Basic and applied aspects of seed biology. Dordrecht: Kluwer Academic; 1997.p.2332. (Current plant sciences and biotechnology in agriculture, 30).

Osborne DJ, Boubriak I, Olivier L. Rehydration of dried systems: membranes and nuclear genome. In: Black M, Pritchard HW, editors. Desiccation and survival in plants: drying without dying. Cambridge: CAB International; 2002. p 64.

Perez SCJGA, Fanti SC, Casali CA. Influência do armazenamento, substrato, envelhecimento precoce e profundidade de semeadura na germinação de canafístula. Bragantia.1999;58(1):57-68.
Roberts EH. Predicting the storage life of seeds. Seed Science and Technology. 1973;1(3):499-514.

Rosseto ES. Comparação ultraestrutural entre folhas hidratadas e dessecadas de três espécies de Velloziaceae: duas revivescentes e uma sensível a dessecação [tese]. Campinas: Universidade Estadual de Campinas; 1997.

Rupollo G, Gutkoski LC, Marini LJ, Elias MC. Sistemas de armazenamento hermético e convencional na conservabilidade de grãos de aveia. Ciência Rural. 2004;34(6):1715-22.

Santos CMR, Menezes NL, Villela FA. Alterações fisiológicas e bioquímicas em sementes de feijão envelhecidas artificialmente. Revista Brasileira de Sementes. 2004;26(1):110-9.

Silva PAS, Diniz KA, Oliveira JÁ, Pinho ÉVR von I. Análise fisiológica e ultra-estrutural durante o desenvolvimento e a secagem de sementes de soja. Revista Brasileira de Sementes. 2007;29(2):15-22.

Stein JC, Hansen G. Mannose induces an endonuclease responsible for DNA laddering in plant cells. Plant Physiology. 1999;121:71-9.

Vertucci CW, Farrant JM. Acquisition and loss of desiccation tolerance. In: Kigel J, Galili G editor. Seed development and germination. New York: M. Dekker; 1995. p.237-71.

Walters C. Levels of recalcitrance in seeds. Revista Brasileira de Fisiologia Vegetal. 2000;12:721. (Edição especial).

Revista Árvore. 2017;41(4):e410411 